УДК 379.852

DOI: 10.25140/2411-5215-2021-1(25)-63-70

Катерина Кудряшова, Галина Рябуха

\title{
ПЕРСПЕКТИВИ РОЗВИТКУ ЕКОЛОГІЧНОГО ТУРИЗМУ В ЧЕРНІГІВСЬКІЙ ОБЛАСТІ
}

\author{
Kateryna Kudriashova, Galyna Ryabukha \\ PROSPECTS OF ECOLOGICAL TOURISM DEVELOPMENT \\ IN CHERNIHIV REGION
}

\begin{abstract}
У статті досліджено дефінічію поняття «екологічний туризм» та визначено місие Чернігівської області за кількістю пам'яток садово-паркового мистеитва. Доведено унікальність Мезинського національного природного парку за різноманітністю флори та фауни. Розроблено перелік правил поведінки на території парку для зменшення антропогенного навантаження на природу. Висвітлено характеристики екостежки на території «Рихлівської дачі». Проаналізовано сучасний стан інтернет-маркетингу природних парків та виявлено необхідність створення додаткових інструментів просування Мезинського національного природного парку. Доведено перспективність соціальних мереж Instagram ma TikTok та запропоновано змістовний контент.

Ключові слова: екологічний туризм; Мезинський національний природний парк; екотежка; інтернетмаркетинг; Instagram; TikTok

Рис.: 3. Табл.: 2. Бібл.:16

The article examines the definition of "ecological tourism" and identifies the place of the Chernihiv region by the number of monuments of landscape art. The uniqueness of the Mezyn National Nature Park in terms of the diversity of flora and fauna has been proved. A list of conduct rules in the park has been developed to reduce the anthropogenic burden on nature. The characteristics of the eco-trail on the territory of "Rykhlivska dacha" are highlighted. The current state of Internet marketing of nature parks was analyzed and the need to create additional tools for promoting Mezyn National Nature Park is revealed. The availability of social networks like Instagram and TikTok was proved and meaningful content was offered.

Keywords: ecological tourism; Mezyn National Nature Park; eco-trail; internet marketing; Instagram; TikTok.

Fig.: 3. Table: 2. References: 16.
\end{abstract}

JEL Classification: Q56; Q57; R11

Постановка проблеми. Розвиток екологічного туризму в Чернігівській області сприяє дослідженню його особливостей та перспектив. Пам'ятка садово-паркового мистецтва - Мезинський національний природний парк є осередком екологічного туризму за унікальність біорізноманіття. Саме тому виявлення інструментів просування з метою розширення аудиторії відвідувачів $є$ необхідним та пріоритетним.

Аналіз останніх досліджень і публікацій. Питанню рекреаційного використання просторових ресурсів присвячені дослідження науковців різних сфер діяльності: економістів, лісівників, екологів, географів, біологів, особливо варто відзначити праці М. Бутка, Б. Данилишина, Ж. Дерій, О. Зеленської, М. Долішнього, О. Тарасової, С. Генсірука, М. Нижник, І. Бойко, О. Фурдичко та інших. Також рекреаційне лісокористування та його вплив на ліси висвітлені у працях О. Данілової, М. Мельнійчука, Т. Павловської, І. Калуцького та інших.

Виділення недосліджених частин загальної проблеми. Дослідження вчених присвячені використанню рекреаційному потенціалу регіонів України. Проте недостатньо уваги приділено можливостям розвитку екологічного туризму з використанням інтернет-маркетингу.

Мета статті. Метою статті є поглиблене дослідження використання потенціалу розвитку екологічного туризму в Чернігівській області на прикладі Мезинського національного природного парку та розробка інструментів інтернет-маркетингу.

Виклад основного матеріалу. Останнім часом посилена увага суспільства звернута до понять зеленого туризму, аграрного туризму, подієвого туризму, освітнього туризму та культурологічного туризму. Усі ці терміни мають багато спільного, але вони не $\epsilon$ синонімами екологічного туризму. Для того щоб зрозуміти, що ж таке «екологічний туризм», у табл. 1 наведено дефініцію цього поняття.

(С) Кудряшова К. М., Рябуха Г. І., 2020 
Дефініція поняття «екологічний туризм»

\begin{tabular}{|l|l|}
\hline $\begin{array}{l}\text { Всесвітній фонд дикої } \\
\text { природи WWF }\end{array}$ & $\begin{array}{l}\text { Це цілеспрямовані мандрівки до природних територій з метою глибшого } \\
\text { розуміння місцевої культури та довкілля, що не руйнують цілісність екосис- } \\
\text { тем та роблять охорону довкілля вигідною для місцевого населення. }\end{array}$ \\
\hline $\begin{array}{l}\text { Гектор Цебаллос- } \\
\text { Ласкурейн }\end{array}$ & $\begin{array}{l}\text { Екологічний туризм поєднує подорожі та дбайливе ставлення до природи, } \\
\text { дозволяє поєднати вивчення зразків флори й фауни, сприяючи їх захисту та } \\
\text { отримуючи радість від знайомства. }\end{array}$ \\
\hline В. І. Гетьман & $\begin{array}{l}\text { Екологічний туризм включає всі види туризму, орієнтовані на збереження } \\
\text { природного довкілля, налагодження стосунків із місцевим населенням, по- } \\
\text { ліпшення фінансово-економічного добробуту регіонів. }\end{array}$ \\
\hline $\begin{array}{l}\text { Міжнародний союз } \\
\text { охорони природи UICN }\end{array}$ & $\begin{array}{l}\text { Це мандрівка з відповідальністю перед довкіллям порівняно недоторканими } \\
\text { природними територіями з метою вивчення та насолоди природними та ку- } \\
\text { льтурними об'єктами, що сприяє охороні довкілля, здійснює «м'який» } \\
\text { вплив на довкілля, забезпечує активну соціально-економічну участь місце- } \\
\text { вого населення та отримання ним користі від цієї діяльності. }\end{array}$ \\
\hline В. В. Храбовченко & $\begin{array}{l}\text { Це вид туризму, що орієнтується на туристичний попит, пов'язаний із пі- } \\
\text { знанням природи і збереженням екосистем при одночасному врахуванні } \\
\text { інтересів місцевого населення. }\end{array}$ \\
\hline
\end{tabular}

Джерело: узагальнено автором на основі $[11 ; 2 ; 15 ;]$.

Досліджуючи сутність терміну «екологічний туризм», варто зазначити, що він має широке тлумачення. Отже, екологічний туризм - це вид туризму з мінімальним антропогенним впливом на навколишнє середовище, який спрямований на ознайомлення, пізнання і збереження природи.

Основними причинами розвитку екологічного туризму є прагнення людей до спілкування з природою, втома від соціальних контактів, вичерпність емоційних ресурсів, зменшення фізичних навантажень (сидячий спосіб життя) та інше. У табл. 2 наведено функції екологічного туризму.

Таблиця 2

Функиії екологічного туризму

\begin{tabular}{|c|c|c|c|c|}
\hline $\begin{array}{c}\text { Пізнавальна } \\
\text { функція }\end{array}$ & $\begin{array}{c}\text { Рекреаційна } \\
\text { функція }\end{array}$ & $\begin{array}{c}\text { Екологічна } \\
\text { функція }\end{array}$ & $\begin{array}{c}\text { Збереження здоров'я } \\
\text { людини }\end{array}$ & $\begin{array}{c}\text { Естетична } \\
\text { функція }\end{array}$ \\
\hline$\downarrow \downarrow \downarrow$ & $\downarrow \downarrow \downarrow$ & $\downarrow \downarrow \downarrow$ & $\downarrow \downarrow \downarrow \downarrow$ & $\downarrow \downarrow \downarrow$ \\
\hline $\begin{array}{l}\text { - Знайомство } 3 \\
\text { різноманіттям } \\
\text { флори і фауни. } \\
\text { - Вивчення біо- } \\
\text { ценозів. }\end{array}$ & $\begin{array}{l}\text { - Активний } \\
\text { відпочинок. } \\
\text { - Зміна ситу- } \\
\text { ації. } \\
\text { - Зняття емо- } \\
\text { ційного на- } \\
\text { пруження. }\end{array}$ & $\begin{array}{l}\text { - Формування } \\
\text { екологічної куль- } \\
\text { тури. } \\
\text { - Забезпечення } \\
\text { екологічної безпе- } \\
\text { ки. } \\
\text { - Взаємодія з ди- } \\
\text { кою природою. }\end{array}$ & $\begin{array}{l}\text { - Свіже повітря: аромо- } \\
\text { терапія, фітонциди. } \\
\text { - Сонячні промені підви- } \\
\text { щують активність кори } \\
\text { головного мозку, позитив- } \\
\text { но впливають на обмін ре- } \\
\text { човин і гормональний фон. } \\
\text { - Мінеральні води мають } \\
\text { цілющі властивості. }\end{array}$ & $\begin{array}{l}\text { - Джерело на- } \\
\text { тхнення для } \\
\text { творців мистец- } \\
\text { тва. } \\
\text { - Задоволення } \\
\text { естетичних уяв- } \\
\text { лень. }\end{array}$ \\
\hline
\end{tabular}

Екологічний туризм призначений для невеликих груп туристів (до 10 осіб), які хочуть більше дізнатись про природу в певній місцевості та допомогти людям, які там живуть. Екотуристи подорожують туди, де головною пам'яткою є життя рослин і тварин. Вони хочуть дізнатись більше про те, як люди живуть поруч із дикою природою.

Чернігівщина посідає одне з провідних місць за кількістю пам'яток культурної спадщини в Україні - понад 9 тис. пам’яток, з них - 1881 національного значення. Зокрема, діє три національні заповідники («Чернігів стародавній», «Гетьманська столиця», «Качанівка») Міністерства культури України та Меморіальний комплекс «Пам'яті Героїв Крут» Міністерства оборони України та 33 музеї комунальної форми власності [9].

Серед перлин туристично-рекреаційного потенціалу області можна визначити пам'ятки садово-паркового мистецтва - Качанівський та Сокиринський палацовопаркові комплекси, Тростянецький дендропарк, а також Мезинський та Ічнянський національні природні парки [1]. 
ПРОБЛЕМИ МЕНЕДЖМЕНТУ ТА РОЗВИТКУ ПРОДУКТИВНИХ СИЛ РЕГІОНУ

Мезинський національний природний парк (далі Мезинський НПП) був створений у 2006 році. Загальна площа парку становить 31 035,2 га.

На території Мезинського НПП виявлено 14 видів судинних рослин, занесених до Червоної книги України (1996). Серед них Allium ursinum L., Huperzia selago L., Platanthera chlorantha Cust., P. bifolia L., Orchis militaris L., Neottia nidus-avis L., Nymphoides peltata O. Kuntze, Salvinia natans L. Listera ovata L, Lycopodium annotinum L., Epipactis helleborine L., Lilium martagon L., Dactylorhiza incarnata L, Epipactis atrorubens Schult.

Рідкісних тварин на території Мезинського НПП нараховується 24 видів. Більшість місцевих тварин, занесених до Червоної книги, - це хребетні тварини. До списку червонокнижних тварин парку увійшли: п'явка медична Hirudo medicinalis L., вусач мускусний Aromia moschata L., красотіл пахучий Calostoma sycophanta L., махаон Papilio machaon L., стрічкарка тополева Limenitis populi L., бражник скабіозовий Haematorus ostralegus L., Джміль моховий Bombus muscorum F., Джміль пахучий Bombus fragrans L., дозорець-імператор Anax imperator Leach, кордулегастер кільчатий Cordulegaster annulatus Latrielle (Безхребетні), стерлядь Acipenser ruthenus L., мідянка Coronella austriaca Laurenti, лелека чорний Ciconia nigra L., змієїд Circaetus gallicus G., лунь польовий Circus eyaneus L., лунь степовий Circus macrourus S. G. Gmelin, шуліка рудий Milvus milvus L., журавель сірий Grus grus L., кулик-сорока Haemantopus ostralegus L., сорокопуд сірий Lanius excubitor L., борсук звичайний Meles meles L., видра Lutra lutra L., горностай Mustela erminea L. (Хребетні) [9].

Дослідження антропогенних чинників впливу на природні комплекси та об'єкти базується на даних моніторингу стану навколишнього природного середовища. На території Мезинського НПП головними чинниками антропогенного впливу є господарська діяльність, серед видів якої найбільш розвинутою є сільське господарство. Ведення сільського господарства, особливо пов'язане з землеробством, потребує застосування хімічних речовин та періодичного порушення поверхневого шару грунту. Випасання худоби, при мозаїчній структурі розміщення заповідних територій, обов'язково вплине на стан їх збереження та буде порушувати заповідний режим території.

Зменшення антропогенного впливу під час відвідування Мезинського НПП туристами досягається шляхом спрямування людей по екостежках, при цьому мінімізується їх перебування за межами стежок. Для цього проводиться благоустрій стежок, зокрема, покриття. У світовій практиці застосовують штучні перешкоди, які розміщені поблизу стежки й ускладнюють пересування відвідувачів за ії межами.

Під час подорожі туристи повинні дотримуватись 10 заповідей екотуриста, які були сформульовані Міжнародним товариством екотуризму (The International Ecotourism Society), a caмe:

1) Пам'ятати про вразливість Землі;

2) залишати тільки сліди, забирати із собою тільки фотографії;

3) пізнавати світ, у який потрапив: культуру народів, географію;

4) шанувати місцевих мешканців;

5) не купувати вироби, що піддають небезпеці довкілля;

6) завжди ходити тільки протоптаними стежками;

7) підтримувати програми захисту довкілля;

8) використовувати методи зберігання довкілля, де це можливо;

9) підтримувати організації, що сприяють захисту природи;

10) подорожувати з фірмами, що у своїй діяльності підтримують принципи екотуризму [16].

На території «Рихлівської дачі» в Мезинському НПП була створена екостежка (рис. 1), яка має 10 основних зупинок [6]. 
ПРОБЛЕМИ МЕНЕДЖМЕНТУ ТА РОЗВИТКУ ПРОДУКТИВНИХ СИЛ РЕГІОНУ

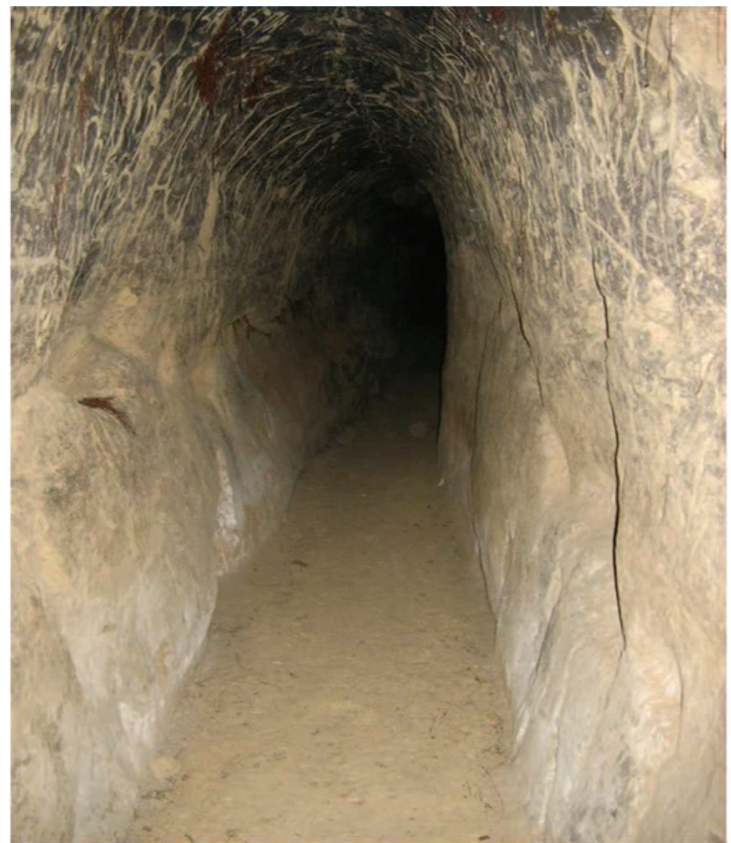

Печера Рихлівського монастиря, кінець XVII cm.

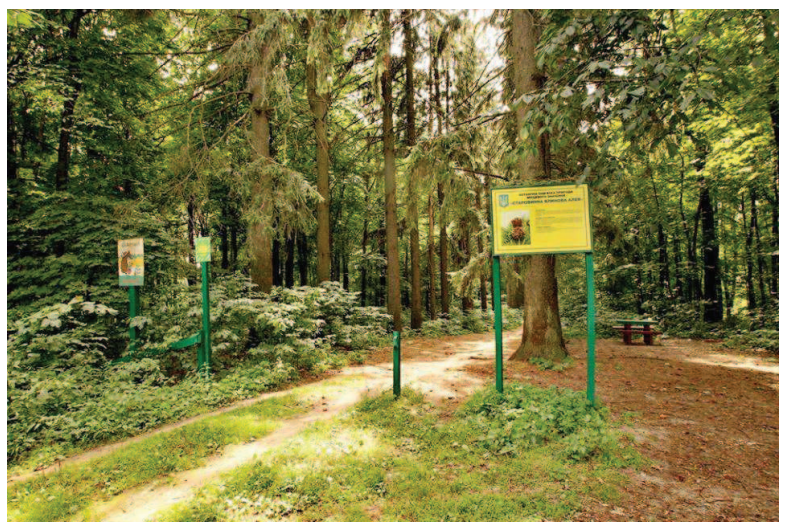

Старовинна ялинова алея

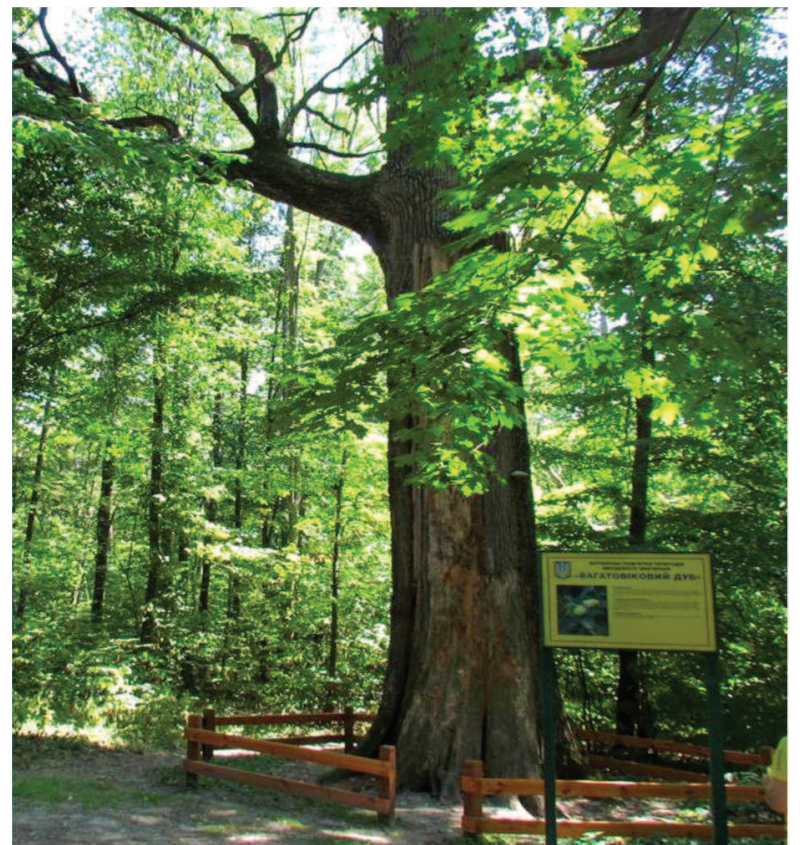

800-річний «Цар дуб»

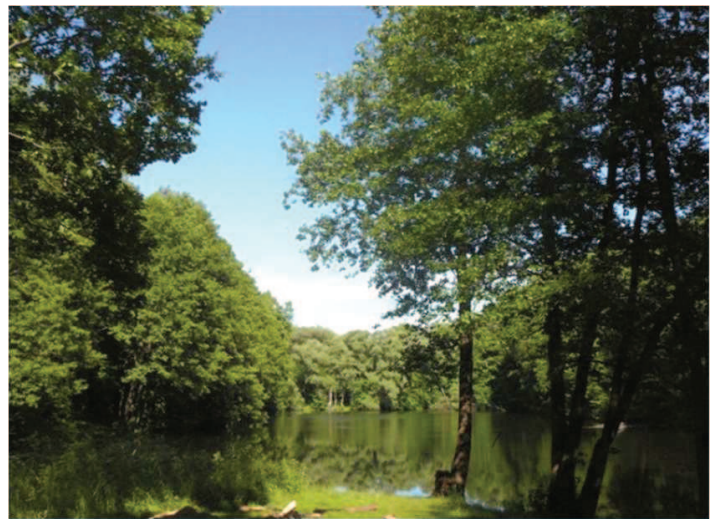

Лісове озеро

Рис. 1. Об'єкти екологічної стежки на території «Рихлівської дачі»

Зупинка 1. Старовинна ялинова алея, яка веде до монастирських печер. Алея складається із ялини європейської висотою понад 30 м у кількості 79 дерев.

Зупинка 2. Каштанова алея, яка веде до пасічного саду, Цар-дуба, не розкопаних печерних лабіринтів та до ставка. На території алеї - 42 дерева каштану кінського віком понад 100 років.

Зупинка 3. Пасічний сад, у якому ростуть вишні, сливи, яблуні, волоські горіхи. Сад знаходиться праворуч дороги, а ліворуч йде стежка до освяченої криниці.

Зупинка 4. Ділянки неморального лісу. Дорога стрімко підіймається вгору та веде до кленово-липового лісу, який вирізняється великою різноманітністю рослинних видів.

Зупинка 5. «Цар-дуб». Дерево віком близько 800 років, окружність стовбура $650 \mathrm{~cm}$.

Зупинка 6. Панорами «Рихлівської дачі». На цій зупинці відкриваються панорами на ставок і на схили «Рихлівської дачі», що зберігають таємниці, порослих лісом, печерних лабіринтів. 
ПРОБЛЕМИ МЕНЕДЖМЕНТУ ТА РОЗВИТКУ ПРОДУКТИВНИХ СИЛ РЕГІОНУ

Зупинка 7. Ставок, навколо порослий лісом, який підходить до води і формує коренями каркас ставка. Якщо спуститися стежкою до ставка, то можна побачити дубдовгожитель віком понад 800 років, діаметр стовбура - 1,8 м, висота - 24 .

Зупинка 8. Понад ставом. Праворуч можна побачити дамбу, яка регулює рівень води в ставку, ліворуч знаходиться заболочений ставок. Далі від ставка знаходиться стара монастирська конюшня.

Зупинка 9. Конюшня - двоповерхова будівля, яку легко побачити. Ліворуч від стежки маршруту розташований старий монастирський сад, який і досі плодить.

Зупинка 10. Монастирські руїни. Далі ліворуч знаходиться хутір Рихли. Закінчення маршруту біля руїн гостинного двору. Тут правіше $є$ три дивних дерева дубів - Дуплистий, Рогатий та Дуб бажань. Їх також варто побачити.

Запорукою формування інтересу та бажання відвідати Мезинський НПП є розвиток інтернет-маркетингу, який створить новий додатковий канал поширення інформації та збільшить зацікавленість потенційних відвідувачів. У результаті покращиться імідж природного парку, а також посиляться додаткові конкурентні переваги [10].

Порівняння інструментів інтернет-маркетингу природних парків та заповідників доводить слабкі позиції Мезинського НПП, Ічнянського НПП, національного історикокультурного заповідника «Качанівка» у порівнянні із парком природи «Беремицьке». Зокрема, у Мезинського НПП є сайт та сторінка Facebook, Ічнянський НПП має лише сайт [3; 4]. Найбільшим арсеналом інструментів інтернет-маркетингу володіє парк природи «Беремицьке», серед них: сайт, сторінки Facebook, Twitter, Pinterest, Instagram, YouTube-канал [5].

Проаналізувавши перспективність інструментарію інтернет-маркетингу, запропоновано створення Instagram-сторінки та профайлу TikTok [7; 8].

Створення Instagram-сторінки дозволить показати унікальність та цінність Мезинського НПП, сформувати зацікавленість потенційних відвідувачів. Для формування контенту сторінки доречним буде розміщення зображень природи із заохоченнями відвідати парк. Наведення цікавих фактів сприятиме інтересу до пізнання та зацікавленості відвідати екскурсії. Відгуки відвідувачів та рекомендацій відомих людей сформують довіру та імідж природного парку.

Відповідно до статистики кількість користувачів Instagram збільшиться до 1180,5 млн до 2023 року, демонструючи стрімкий розвиток (рис. 2) [14].

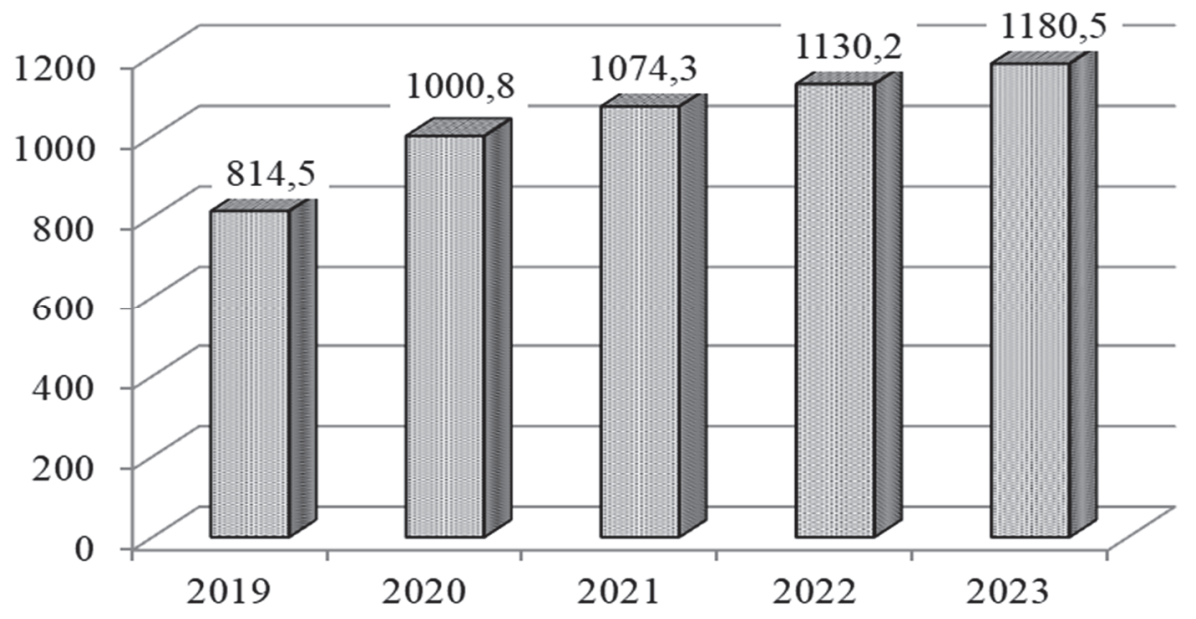

Рис. 2. Прогноз кількості користувачів Instagram до 2023 р., млн чол. 
Перспективною є найбільш динамічна соціальна мережа світу TikTok. Сервіс із музичними відео нараховує понад 2 млрд завантажень та активно розвивається (рис. 3). Варто відзначити, що Україна посідає 25-е місце у світовому рейтингу TikTok за загальною кількістю інфлуенсерів (облікових записів із кількістю підписників понад тисячу) [13].

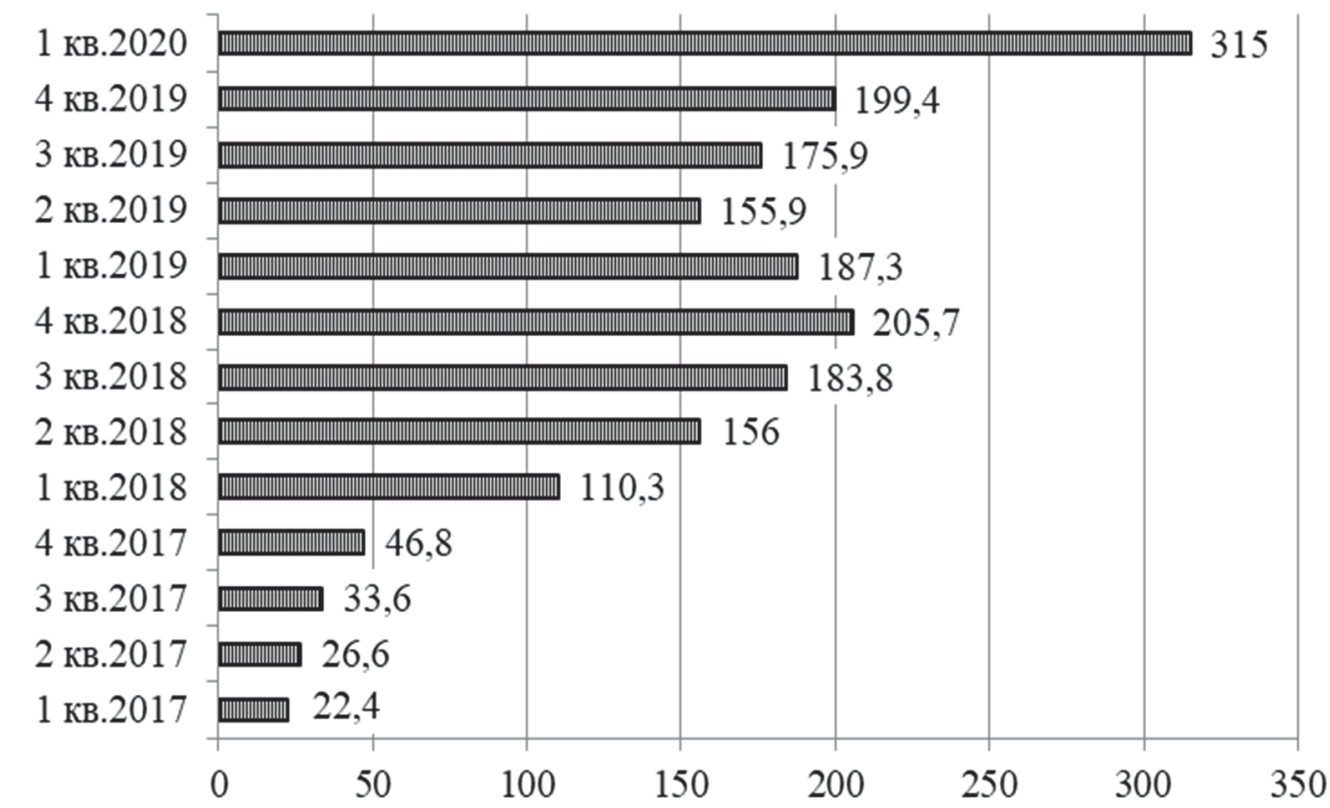

Рис. 3. Кількість завантажень додатку ТісТок протягом 2017-2020 рр., млн

На основі статистичних даних можна зробити висновок, що у квітні 2020 року була завантажена рекордна кількість - 315 млн. Варто також зазначити, що у квітні 2020 року TikTok подолав позначку у 2 млрд завантажень з більш ніж 150 країн світу [12].

Контент TikTok повинен бути орієнтований на проведення коротких відеолекцій про природу парку, онлайн-екскурсій, а також розміщення відео відомих людей. Для цього можна заохотити їх наданням безкоштовних додаткових послуг (екскурсій, фотосесій). Для популяризації Мезинського НПП у соціальних мережах доречним буде створення тематичних фотолокацій. Візуалізація мальовничих місць сприятиме формуванню бажання відвідати природний парк та створити власні фотознімки.

Запорукою успішного просування є регулярність публікації матеріалів, цікавий контент, розробка заохочувальних акцій і проведення цікавих заходів.

Висновки і пропозиції. Таким чином, можна зробити висновок, що розвиток екологічного туризму в Чернігівській області - один із пріоритетних напрямів покращення стану природних територій, ознайомлення та вивчення біоценозів, формування екологічної культури. 3 кожним роком зростає зацікавленість туристів до пізнання природи. Мезинський НПП є унікальним за кількість біорізноманіття у поєднанні зі стоянкою первісної людини, проте не визначається достатньою кількістю та якістю популяризації в соціальних мережах. Розвиток інтернет-маркетингу зі створення сторінок в Instagram та TicTok дозволить створити імідж, підвищити конкурентоспроможність, розширити аудиторію відвідувачів. Подальші дослідження рекомендовано спрямувати на розробку цілісної маркетингової стратегії Мезинського НПП.

\section{Список використаних джерел}

1. Бутко М. П., Самко О. О. Особливості формування та функціонування регіонального ринку туристичних послуг. Продуктивні сили і регіональна економіка. 2008. Ч. 2. С. 53-64. 
ПРОБЛЕМИ МЕНЕДЖМЕНТУ ТА РОЗВИТКУ ПРОДУКТИВНИХ СИЛ РЕГІОНУ

2. Гетьман В. І. Основні завдання і проблеми розвитку екотуризму в національних природних парках і біосферних заповідниках України. Гори і люди (у контексті сталого розвитку) : матеріали Міжнар. конф. присвяченої Міжнар. року гір (м. Рахів, 14-18 жовтня 2002 р.). Рахів, 2002. T. 1. C. $304-313$.

3. Ічнянський національний природний парк : офіціцний сайт. URL: http://ichn-park.in.ua.

4. Мезинський національний природний парк: офіційний сайт. URL: http://mezinpark.com.ua.

5. Парк природи «Беремицьке». URL: https://beremytske.com.ua.

6. Проект організації території, охорони, відтворення та рекреаційного використання природних комплексів та об'єктів Мезинського НПП. Харків, 2010. Т. 1. Пояснювальна записка, книга I. 254 c.

7. Соціальна мережа «Інстаграм». URL: https://www.instagram.com.

8. Соціальна мережа «Тікток». URL: https://www.tiktok.com.

9. Туристична галузь Чернігівщини / Чернігівська обласна державна адміністрація. URL: https://cg.gov.ua/index.php?id=1756\&tp=1.

10. Шабардіна Ю. В. Організаційно-економічний механізм розвитку рекреаційного потенціалу регіону. Вісник Чернігівського державного технологічного університету. 2014. № 2(74). C. 126-133.

11. A word without nature. URL: https://www.worldwildlife.org.

12. Gain Valuable Insights on the Greater App Economy. URL: https://sensortower.com.

13. Industry Standard Analytical Platform for transparent \& fraud-free influencer marketing. URL: https://hypeauditor.com.

14. Introducing Financial Services from Insider Intelligence. URL: https://www.insiderintelligence.com.

15. IUCN, International Union for Conservation of Nature. URL: https://www.iucn.org.

16. The International Ecotourism Society. URL: https://ecotourism.org.

\section{References}

1. Butko, M. P., Samko, O. O. (2008). Osoblyvosti formuvannia ta funktsionuvannia rehionalnoho rynku turystychnykh posluh [Features of formation and functioning of the regional market of tourist services]. Produktyvni syly i rehionalna ekonomika - Productive forces and regional economy, 2, pp. 53-64.

2. Hetman, V. I. (2002). Osnovni zavdannia i problemy rozvytku ekoturyzmu v natsionalnykh pryrodnykh parkakh i bios-fernykh zapovidnykakh Ukrainy [The main tasks and problems of ecotourism development in national nature parks and biosphere reserves of Ukraine]. Hory i liudy ( $u$ konteksti staloho rozvytku): materialy Mizhnar. konf. prysviachenoi Mizhnar. roku hir - Mountains and people (in the context of sustainable development): materials International. conf. dedicated to the International. year of the mountains (Vol. 1, pp. 304-313).

3. Ichnianskyi natsionalnyi pryrodnyi park: ofitsitsnyi sait [Ichnia National Nature Park: official site]. http://ichn-park.in.ua.

4. Mezynskyi natsionalnyi pryrodnyi park: ofitsiinyi sait [Mezyn National Nature Park: official site]. http://mezinpark.com.ua.

5. Park pryrody «Beremytske» [Beremitske Nature Park]. https://beremytske.com.ua.

6. Proekt orhanizatsii terytorii, okhorony, vidtvorennia ta rekreatsiinoho vykorystannia pryrodnykh kompleksiv ta obiektiv Mezynskoho NPP [Project of organization of the territory, protection, reproduction and recreational use of natural complexes and objects of Mezynsky NNP] (2010). (Vol. 1).

7. Sotsialna merezha «Instahram» [Social network «Instagram»]. https://www.instagram.com.

8. Sotsialna merezha «Tiktok» [Social network «Tiktok»]. URL: https://www.tiktok.com.

9. Chernihivska oblasna derzhavna administratsiia [Chernihiv Regional State Administration]. Turystychna haluz Chernihivshchyny [Tourism industry of Chernihiv region]. https://cg.gov.ua/index.php?id=1756\&tp=1 . 
10. Shabardina, Yu. V. (2014). Orhanizatsiino-ekonomichnyi mekhanizm rozvytku rekreatsiinoho potentsialu rehionu [Organizational and economic mechanism development regional recreation potential]. Visnyk Chernihivskoho derzhavnoho tekhnolohichnoho universytetu - Visnyk of Chernihiv State Technological University, 2(74), pp. 126-133.

11. A word without nature. https://www.worldwildlife.org.

12. Gain Valuable Insights on the Greater App Economy. https://sensortower.com.

13. Industry Standard Analytical Platform for transparent \& fraud-free influencer marketing. https://hypeauditor.com.

14. Introducing Financial Services from Insider Intelligence. https://www.insiderintelligence.com.

15. IUCN, International Union for Conservation of Nature. https://www.iucn.org.

16. The International Ecotourism Society. https://ecotourism.org.

Кудряшова Катерина Миколаївна - кандидат економічних наук, доцент кафедри аграрних технологій та лісового господарства, національний університет «Чернігівська політехніка» (вул. Шевченка, 95, м. Чернігів, 14035, Україна).

Kudriashova Kateryna - PhD in Economics, Associate Professor of Agricultural Technologies and Forestry Department, Chernihiv Polytechnic National University (95 Shevchenka Str., 14035 Chernihiv, Ukraine).

E-mail: Katrinchernigov@gmail.com

ORCID: https://orcid.org/0000-0002-5626-0958

Рябуха Галина Ігорівна - кандидат економічних наук, доцент кафедри туризму, національний університет «Чернігівська політехніка» (вул. Шевченка, 95, м. Чернігів, 14035, Україна)

Ryabukha Galyna - PhD in Economics, Associate Professor of Tourism Department, Chernihiv Polytechnic National University (95 Shevchenka Str., 14035 Chernihiv, Ukraine).

E-mail: g.ryabukha@gmail.com

ORCID: https://orcid.org/0000-0003-2146-7489

Кудряшова К., Рябуха Г. Перспективи розвитку екологічного туризму в Чернігівській області. Проблеми і перспективи економіки та управління. 2021. № 1(25). С. 63-70. 